\title{
Analyzing the Readiness of Junior High School Educators In the Online Learning Implementation During Covid-19: An Interview Study
}

\author{
Hulman Sihombing, Betty A.S.Pakpahan, Meditatio Situmorang \\ Institut Agama Kristen Negeri Tarutung \\ E-mail address bas.pakpahan@yahoo.com
}

\begin{abstract}
This research has the purpose of finding out the ReadinessReadiness of junior high school teachers in the online learning, and efforts which are carried out as well as obstacles that are dealt with in the online learning implementation at the time of Covid-19 pandemic. The kind of research which is used is qualitative-descriptive, with the interview technique. The result of the research shows that the junior high school educators enthusiastically respond the online learning by preparing the online learning devices and promoting the change of learning system to the students, and the online learning system is executed by utilizing applications, such as short message service, Whatsapp group, Zoom, phone, or live chat. The result of this research shows that junior high school teachers are ready to implement online learning in spite of not being optimal and dealing with various obstacles.
\end{abstract}

Keywords: Readiness, Educator, Online Learning

\section{INTRODUCTION}

The information technology advance has a wide impact on various human life aspects, including education, so that it encourages the educators to be ready to deal with various changes, including the learning pattern. Keengwe \& Georgina (2012), in their research stated that "the development of technology offers the change toward the teaching and learning implementation." 1 If the educators are all this time comfortable with the traditionally conventional learning, it is time to change and adapt with the demand of 4.0 industrial revolution era, which concerns more on digital technology in the learning process or is well known as a cyber system. This system is able to force the learning process to run continually without any limit of time and space. In line with the demand of 4.0 industrial revolution demand, it needs the school reformation, dynamic enhancement, the professionalism of educators, dynamic curricula, reliable facilities and infrastructure, and up-to-date learning technology, especially for education doers who are directly involved in interacting with the students, namely the Educators must be able to master information technology and be able to teach the material with an approach of applying the information technology use in the learning process, so it produces graduates who are superior and capable to compete globally. International Education Advisory Board (2017) states that "Every teacher is not excluded from the need for these skills. The development for all education is highly important to ensure that the technology is able to be used easily in the learning process and is able to facilitate the implementation of education. The sufficient equipment will not be useful unless it is accompanied by human resources who are capable of utilizing it" (International Education Advisory Board, 2017). 
To answer the needs of the 4.0 industrial revolution era, it has actually been started since the 2013/2014 academic year. The government has implemented a new curriculum called the 2013 Curriculum. The implementation of the curriculum is regulated in Permendikbud No. 81A/2013. This is due to the challenges dealt with by Indonesia, including the internal challenges and the external challenges. The internal challenges are related to factors in the development of Indonesia's population in terms of population growth in productive age. Meanwhile, the external challenges are the global changes and free-market competition, as well as the demands for advances in science and technology (Mulyasa, 2013: 5). 3 The 2013 Curriculum has required the teachers to master the information and communication technology (ICT) so that the ICT subject does not longer appear as a subject but has been integrated into the learning process. The ability to master and to use communication information technology is highly important for the teachers to face the future.

But in fact, the results of a 2018 survey by the Center for Information and Communication Technology for Education and Culture (Pustekkom) of the Ministry of Education and Culture (Kemendikbud) explained that $40 \%$ of teachers in Indonesia are already literate in information and communication technology (ICT). The rest, $60 \%$ percent of teachers, still stutter with the advancement in the digital era. 4 This fact is more obvious in the condition of the Covid-19 pandemic. Many educators, students, and even parents are shocked and confused with the enactment of the physical distancing policy. Due to the Covid-19 pandemic, the government, through the Ministry of Education and Culture, issued Circular No. 3/2020 concerning the Prevention of Covid-19 in the Educational Unit and No. 36962 / MPK.A / HK / 2020 concerning the online learning and work-from-home in the Context of Preventing the Spread of Covid-19.

This government policy requires educators to leave their comfort zone and be prepared to adapt to online learning. Online learning is a solution for implementing learning from home. Learning in a network (online) is learning without face-to-face directly between the teachers and students, but is carried out online using the internet network. Online learning requires the creativity and innovation of the educators so that the students feel comfortable and do not feel bored in following the learning. According to Siswandari, "Teachers must be creative, both in terms of pedagogy or how to teach as well as in terms of the technology that is used."5 From the pedagogical point of view, the educators, must be able to determine various approaches, strategies, methods, and learning techniques that educate creatively, and be able to adjust the learning methods according to the characteristics of the students and motivate them to learn: Meanwhile, from the technology point of view, the educators are required to be able to create and innovate in the online learning, such as through virtual forms of videos, films, animation, simulations, and online practices. With the existence of variations in the use of information and communication technology (ICT) in the learning process, students will be more pleased to take part in learning.

The Covid-19 pandemic has caused anxiety for human life, but on the other hand, the Covid-19 pandemic has become a driving force for the educators to implement a technology-based learning system, the educators inevitably have responded to government policies by implementing an online learning system, and this is a support for the 4.0 industrial era. Even though online learning is not yet optimal, at least the educators have tried to implement it because a change requires an adjustment. Based on this description, this research will describe the ReadinessReadiness of junior high school teachers to face the online learning during the Covid-19 pandemic, what efforts have been made and the obstacles experienced during the online learning. 


\section{LITERATURE REVIEW}

\section{II.1. READINESS}

The term Readiness has the same meaning as willingness, volition, availability, capability. Readiness is a state of getting ready to prepare something (The Great Dictionary of Indonesian Language). That ReadinessReadiness arises from a person's oneself and is related to maturity because maturity means the ReadinessReadiness to carry out the proficiency. This is in line with the notion of psychological ReadinessReadiness, which is a point of maturity to accept and practice certain behaviors.

According to Cronbach in Wasty (2006: 191), ReadinessReadiness is all the qualities or strengths that make a person react in a certain way.6 Meanwhile, Slameto (2010: 113) defines that ReadinessReadiness is the overall condition of a person which makes him ready to respond/answer in a certain way toward a situation.7 Furthermore, Dalyono (2005: 52) emphasizes that ReadinessReadiness is a fairly good ability physically, mentally and the learning equipment. 8 Physical readiness means sufficient energy and good health, while mental ReadinessReadiness means having sufficient interest and motivation to do something. In accordance with some definitions above, it can be synthesized that ReadinessReadiness is a person's willingness to respond to a situation in a certain way and has sufficient physical, mental capability, and teaching equipment.

\section{II.2. EDUCATOR}

Educators are the educational personnel who are qualified as teachers, lecturers, counselors, tutors, instructors, facilitators, and other designations that are in accordance with their specialties and participate in the educational implementation (the Republic of Indonesia Law No. 20/2003).9 In this paper, the educator, referred to as the teacher who teaches in Junior High School (SMP) who is in charge of planning and implementing the learning process, assessing the learning outcomes, guiding and training the students. The definition of a teacher in English is "Someone who dedicates himself to provide the knowledge, teach, educate, direct, improve, and train his students to understand the

The knowledge he teaches". This means that a teacher (educator) is Someone who dedicates himself to provide the knowledge, teaching, educating, directing, improving, and training his students to understand the knowledge he teaches. An educator does not only teach formal education, such as school lessons but must be able to educate and shape the character of the students who have noble character. As stated by Alwen Bantry, "The teacher's duty is not only to convey the subject in class but also to be able to set a good example, to be a role model for the students." 10 The teacher is a professional educator with the main task of educating, teaching, guiding, directing, training, assessing, and evaluating students in early childhood education through formal primary education and secondary education.

Educators have such a vital role in creating an educational atmosphere that is meaningful, fun, creative, dynamic, and dialogical, having the ability to teach in accordance with their fields, having high enthusiasm, and having high initiative and willingness, and having the optimal energy in carrying out their professional duties.

\section{II.3. ONLINE LEARNING}

Online learning has the same concept as e-learning, online classroom, virtual learning, or Information and Communication Technology (ICT)-based learning system. According to Riyana, online learning is a system that can facilitate students to learn more widely, more varied, and more differently. Through the facilities provided by this system, the students can study anytime and anywhere without being limited by distance, space, and time. The learning material studied is more varied, not only in verbal form, but also more varied, such as visual, audio, and motion. 11 This learning is also called long-distance learning that uses computer devices or interconnected gadgets where the educators and the students communicate 
interactively by utilizing the communication and information media. This learning is highly dependent on an internet network connection that connects the teachers and the students. The educators can learn together at the same time by using groups on social media, such as WhatsApp (WA), Telegram, Instagram, Zoom application, or other media as the learning media. Gikas \&Grant, 2013) argues that at the implementation level, online learning requires the support of mobile devices, such as smartphones or Android phones, laptops, computers, tablets, and iPhones, which can be used to access the information anytime and anywhere.

So that the more dominant role of the educators in online learning is as a facilitator. According to Robin M and Frank R (2010: 14) that in online learning, teachers, lecturers, tutors, instructors become facilitators, guides, or even expert resource persons, and are no longer the only determinants of the students' learning experience. The educators as facilitators carry out and facilitate the learning activities, prepare everything that can stimulate the students to be able to learn independently, such as; subject matter that can be accessed by the students, making syllabus, lesson plans, preparing material, assessments, discussions, and others. Cepi Riyana said that the role of these educators can run well if the educators have the following competence: 1) Mastering and updating the development of the Internet, 2) Mastering more basic and companion science, 3) Being creative and innovative in presenting material, 4) Being able to motivate the students, 5) Having the ability in Designing the Online Learning, 6) Having the ability to Manage the Online Learning System, 7) Having the accuracy in the Selection of the Online Learning Teaching Materials, 8) Having the ability to Control the Learning Process (Hardianto, there are eight competencies that must be possessed by an online learning teacher).

\section{DISCUSSION}

Based on the interview result with the junior high school educators, their ReadinessReadiness in implementing online learning is the willingness and ability of the educators to respond to any situation in certain ways. The ReadinessReadiness of those educators is shown through the willingness and resilience of the teachers to deal with the sudden changes due to the Covid-19 pandemic. The educators do not just give up without doing anything, but the educators think about and prepare the devices and applications to be used in online learning, execute the massive and structured socialization to the

Students and parents. The meaning of "massively" here is to convey the telephone numbers, WA, and e-mails to all students who take subjects that are taught by the educators at school, while "structured" means that they are in a neatly arranged and organized state, that the educator has redesigned the teaching schedules, teaching methods, and teaching duration. So, with this socialization, the educators, students, and parents can collaborate well for the continuity of the learning. This is in line with the opinion of Sobron et al. (2019) that the ReadinessReadiness that must be prepared by the teachers in the first online learning is the sufficient facilities and infrastructure, such as Wifi, computer/laptop, screen, projector, then one of the most vital preparedness in the online learning, namely the school data as well as the delivered information is accepted well by the students. Then, the human resources in executing the online learning program, such as preparing the material which will be delivered to the students.

For the continuity of the learning system during the Covid-19 pandemic, the educators are trying to use Information and Communication Technology (ICT) with smartphone devices, Computers, and Laptops. The simplest application to use is SMS and WhatsApp (WA) to send the course materials to the students because SMS and WhatsApp applications were commonly used before Covid-19, to contact, to ask about assignments, to have discussions, or various things that students and educators need. Meanwhile, the applications which are used by more established educators include Zoom, Google Classroom, animation learning videos, and others. Based on the results of research by Syamsul Jamal (2020), the score for the ReadinessReadiness of e-learning during the Covid-19 pandemic by the teacher is 4.2. This means that the teacher is ready to implement the e-learning, and it can be continued. 
The availability of an internet network is a major obstacle in online learning during the Covid-19 pandemic. The results of the Quick Survey on Learning From Home

In the Covid-19 Prevention Period, the Ministry of Education and Culture in April 2020 showed that the teachers who provided the learning from home experienced the obstacles in the forms of 1) internet network barrier which is inadequate. This obstacle occurred in the 3T and non-3T regions, with a percentage of 21.3 percent and 20 percent, respectively. 2) Teachers also experienced difficulties in observing the students' progress with a percentage of 19.6 percent for teachers in 3T areas and 20.5 percent for teachers in non-3T areas. 3) Teachers find it difficult to coordinate with the students' parents because they have not been able to optimize the digital devices, 4) Teachers are less concentrated in teaching and guiding students. 5) Difficult to give an assessment, 6) do not have the necessary equipment, such as laptop or computer. 7) Teachers also have difficulty in coordinating with other teachers or school principals, and students lack discipline.

Furthermore, Henry Aditia Rigianti's research results (2020) show that the obstacles experienced by the teachers during online learning are the learning applications, the internet networks and devices, the learning management, the assessment, and the supervision.19 Apart from the obstacles stated above, there is no national standard curriculum available for learning during the Covid-19 period.

In addition to online learning, the educators also try to visit the students personally at home, due to the poor internet network, lacking mastery in the use of information and communication technology and not having an Android cellphone. This is in line with the finding, several other forms of effort made by the schools using non-electronic media due to the limited access and abilities, so that the Educators visit the students' houses and monitor remotely by implementing the physical distancing strategies, give questions periodically and give them to the students to be finished at home, give the textbooks to the students, so they can study at home, give the assignments before the day-off, coordinate with the parents regarding the student assignments, design the simple learning activities, by adjusting to Covid-19 prevention situation, such as healthy living and protect the environment".

\section{CONCLUSION AND SUGGESTION}

\section{Conclusion}

The Covid-19 pandemic situation has encouraged the junior high school level educators to respond well to online learning by equipping themselves and mastering the information and communication technology and adjusting the applications that are used according to the abilities of educators and students in the process of teaching and learning activities. The willingness and ability of educators to respond to sudden changes is a big asset in facing the 4.0 industrial era.

\section{Suggestion}

The advances in science and technology are always changing, so educators must be dynamic in responding to any changes that occur by increasing the quality of their mastery of information and communication technology.

\section{REFERENCES}

Atmaka, Dri. 2004. Tips Menjadi Guru Kreatif. Bandung. Yrama Widya Dalyono (2005), Psikologi Pendidikan, Jakarta :Rineka CiptA

Gikas, J., \& Grant, M. M. (2013). Mobile computing devices in higher education: Student perspectives on learning with cellphones, smartphones \& social media. Internet and Higher Education. https://doi.org/10.1016/jjheduc.2013.06.002 
Hamid Muhammad Plt. Dirjen Paud Dikdasmen Kemdikbud, Menyiapkan Pembelajaran di Masa Pandemi: Tantangan dan Peluang, https://spab.kemdikbud.go.id/wpcontent/uploads/2020/07/Menyiapkan-Pembelajaran-di-Masa-Pandemi-

Henry Aditia Rigianti (2020), Kendala Pembelajaran Daring Guru Sekolah Dasar di Kabupaten Banjarnegara, Elementary School 7 (2020) 297-302 e-ISSN 2502-4264 Volume 7 nomor 2 Juli 2020

International Education Advisory Board. (, 2017). Learning in the 21st Century: Teaching

Today's Students on Their Terms. USA: Certiport. International Education

Advisory Board. (, 2017). Learning in the 21st Century: Teaching Today's

Students on Their Terms. USA: Certiport

Jamal Syamsul (2020), Analisis Kesiapan Pembelajaran E-learning Saat Pandemi Covid-19 Di SMK Negeri 1 Tambelangan, Jurnal Nalar Pendidikan Volume 8, Nomor 1, Jan-Jun 2020 ISSN: 23390794 Halaman 17.

Keengwe, J., \& Georgina, D. (2012). The digital course training workshop for online learning and teaching. Education and Information Technologies, 17(4), 365-

379. https://doi.org/10.1007/s10639-011-9164-x

Mulyasa, 2013, Pengembangan dan implentasi pemikiran kurikulum. Rosdakarya bandung.

Slameto. 2010. Belajar dan faktor-faktor yang mempengaruhinya (Cetakan 5). Jakarta:

Rineka Cipta

Sobron, Bayu, Rani, \& Suswandari, M. (2019). Pengaruh Daring Learning terhadap HasilBelajar IPA Siswa Sekolah Dasar. Seminar Nasional Sains Dan Entrepreneurship VI, 1(1), 1-5.

Wasty Soemanto. (2006). Psikologi pendidikan:Landasan kerja pemimpin pendidikan (Cetakan ke 5). Jakarta: Rineka Cipta

https://www.republika.co.id/berita/pendidikan/eduaction/18/12/03/pj60ej335-kemendikbud-hanya-40persen-guru-siap-dengan-teknologi

https://republika.co.id/berita/qdvhwv414/guru-dituntut-lebih-kreatif-dalam-pembelajaran-daring

https://www.metroandalas.co.id/berita-guru-bukan-hanya-mengajar-tapi-juga-mendidik.html

https://www.republika.id/posts/8553/banyak-kendala-belajar-daring-diakali 